\title{
Actions of Angiotensin II and Dopamine in the Medial Preoptic Area on Prolactin Secretion
}

\author{
C. M. LEITE ${ }^{2}$, G. J. R. MACHADO' ${ }^{1}$, R. C. M. DORNELLES ${ }^{1}$, C. R. FRANCI ${ }^{2}$ \\ ${ }^{1}$ Department of Basic Science, Faculty of Odontology, University of Estadual Paulista, Araçatuba, \\ Brazil, ${ }^{2}$ Department of Physiology, Faculty of Medicine of Ribeirão Preto, University of São Paulo, \\ Av. Bandeirantes, Ribeirão Preto, Brazil
}

Received October 11, 2005

Accepted December 29, 2006

On-line available January 2, 2007

\begin{abstract}
Summary
Dopamine (DA) is known as a primary regulator of prolactin secretion (PRL) and angiotensin II (Ang II) has been recognized as one brain inhibitory factor of this secretion. In this work, estrogen-primed or unprimed ovariectomized rats were submitted to the microinjection of saline or Ang II after previous microinjection of saline or of DA antagonist (haloperidol, sulpiride or $\mathrm{SCH}$ ) both in the medial preoptic area (MPOA). Our study of these interactions has shown that 1 ) estrogen-induced PRL secretion is mediated by Ang II and DA actions in the MPOA, i.e. very high plasma PRL would be prevented by inhibitory action of Ang II, while very low levels would be prevented in part by stimulatory action of DA through $D_{2}$ receptors, 2) the inhibitory action of Ang II depends on estrogen and is mediated in part by inhibitory action of DA through $D_{1}$ receptors and in other part by inhibition of stimulatory action of DA through $D_{2}$ receptors.
\end{abstract}

\section{Key words}

Prolactin • Medial preoptic area • Angiotensin II • Dopaminergic antagonists • Estrogen

\section{Corresponding author}

Celso Rodrigues Franci, Departamento de Fisiologia, Faculdade de Medicina de Ribeirão Preto, Universidade de São Paulo, Av. Bandeirantes, 3900 - Campus USP, 14049-900, Ribeirão Preto, SP, Brazil, Fax: +55-16-3633 0017, E-mail: crfranci@fmrp.usp.br

\section{Introduction}

The control of prolactin (PRL) secretion depends on the balance between the action of releasing (PRF) and inhibiting (PIF) factors. Dopamine (DA) has been recognized as the primary regulator of PRL synthesis and release. However, other hypothalamic, systemic and local factors act as inhibitors and stimulators (Ben-Jonathan and Hnasko 2001, Freeman et al. 2000). These factors include gamma aminobutyric acid (Schally et al. 1977), neuropeptide Y (Rettori et al. 1990, Silveira and Franci 1999), atrial natriuretic peptide (Franci et al. 1992, Samson et al. 1988), oxytocin (Samson et al. 1986) and angiotensin II (Ang II) (Franci et al. 1997, Steele et al. 1981), among others.

The rostral group of neurons in $A_{14}$ nucleus, a periventricular structure, is responsible for DA innervation of the medial preoptic area (MPOA). This suggests that the MPOA as part of the incertohypothalamic dopamine system may have involvement in neuroendocrine mechanisms (Björhlund et al. 1975, Day et al. 1980, Lindvall et al. 1984). The periventricular preoptic area neurons project heavily to the arcuate nucleus and median eminence (Conrad and Pfaff 1975). Studies that used transection techniques showed the interaction between preoptic area and medial basal hypothalamus, which contains the PRL-regulating tuberoinfundibular dopaminergic (TIDA) neurons (Arai and Yamanouchi 1975, Carrer and Taleisnick 1970). Basal plasma PRL was higher in deafferentated rats that showed persistent estrus relative to the deafferentated and sham-deafferentated rats that showed regular cycle. This may indicate that preoptic area neurons participate in the tonic hypothalamic inhibition of basal PRL secretion or the deafferentation disinhibited PRL-releasing factor pathways (Jakubowski et al. 1988). Preoptic-anterior hypothalamic area neurons that facilitate PRL secretion 
may either stimulate the secretion of some PRF or inhibit the secretion of some PIF into the hypophysial portal vasculature (Day et al. 1982). Tissue extracts from this area have been reported to exhibit PRF activity in vitro (Krulich et al. 1971).

Hormonal state of an intact female influences the DA activity in the MPOA (Matuszewich et al. 2000). Estrogen stimulates the PRL secretion when is implanted into the preoptic area (Pan and Gala 1985).

MPOA shows angiotensin II (Ang II)-stained cell bodies (Lind et al. 1985), angiotensinogen mRNA, immunoreactive angiotensinogen, angiotensin converting enzyme, immunoreactive angiotensin II, angiotensin II binding sites (Bunnemann et al. 1993) and $\mathrm{AT}_{1}$ receptors (Phillips et al. 1993). Intracerebroventricular microinjection of Ang II decreases (Myers and Steele 1991) while of specific antiserum against Ang II increases plasma PRL (Franci et al. 1997) in estrogen-primed ovariectomized rats. Intracerebroventricular microinjection of Ang II excites a large proportion of neurons in the preoptic-anterior hypothalamic area, increasing the neuronal discharge frequency (Gronan and York 1978) and facilitating the release of norepinephrine and DA (Quadri et al. 1991, Summers and Phillips 1983). Microinjection of Ang II into the MPOA decreased plasma PRL in estrogen-primed ovariectomized rats. This response was blocked by losartan, an $\mathrm{AT}_{1}$ receptor antagonist (Dornelles and Franci 1998a), but it was not altered by alpha- or beta-adrenergic antagonists (Dornelles and Franci 1998b).

Considering that: 1) Ang II and DA act on PRL secretion, 2) the influence of estrogen on Ang II and DA activity in the preoptic area, we aimed to verify in this work: a) if the Ang II action in the MPOA on PRL secretion would be mediated by $\mathrm{D}_{1}$ and/or $\mathrm{D}_{2}$ receptors as well, and b) if the presence or absence of estrogen would modify this putative interaction.

\section{Methods}

Animals

Adult female Wistar rats weighing 180-200 g were kept in a light- and temperature-controlled environment (lights on from 7:00 to 19:00 h, $22 \pm 2{ }^{\circ} \mathrm{C}$ ), with free access to water and food.

\section{Surgery and treatments}

All rats were ovariectomized (OVX) and 14 days later a unilateral stainless-steel cannula was implanted into the MPOA at the following coordinates: $\mathrm{AP}=2.2$, $\mathrm{L}={ }_{ \pm} 0.8, \mathrm{~V}=-7.9$ using a stereotaxic instrument (Kopf, USA). The guide cannula was fixed to the skull with two screws and dental cement (Simplex Dental, Brazil). A mandril was used to prevent obstruction of the cannula. Animals were returned to individual cages after surgery carried out under sodium thiopental anesthesia (50 mg/kg, i.p., Abbott Laboratories, USA). An antibiotic (veterinary pentabiotic, Wyeth Ayerst, USA, $0.2 \mathrm{ml} / \mathrm{rat}$ ) was injected intramuscularly following the two surgeries. One week after stereotaxic surgery, the animals were subcutaneously injected with estradiol benzoate ( $25 \mu \mathrm{g} / 0.5 \mathrm{ml}$ vegetable oil, Schering- Kenilworth, USA, $\mathrm{BE}$ group) or vehicle oil (0.5 ml, OV group) for 3 days. On day 3, $24 \mathrm{~h}$ before the experiment, the animals were anesthetized i.p. with $1 \mathrm{ml}$ of tribromoethanol (Aldrich Chem., USA) $2.5 \%$ in saline/100 g b.w. for insertion of the intra-atrial catheter (tubing with a $0.020 \times 0.037$ diameter, Dow Corning, USA) through the jugular vein.

\section{Experimental procedures}

On the day of the experiment, between 8:30 to 9:00 h, an extension of polyethylene tubing (PE 50) filled with heparin solution $(1: 40)$ in $0.9 \% \mathrm{NaCl}$ was attached to the distal end of the jugular cannula. After $30 \mathrm{~min}$, heparinized blood samples $(0.8 \mathrm{ml})$ were collected from the external jugular vein at the following intervals: -20 (basal bleeding), 0, 10, 20, 30 and $60 \mathrm{~min}$, while the animal was freely moving in the cage. The volume of all samples was replaced immediately after each bleeding with an equivalent volume of saline $(0.15 \mathrm{M} \mathrm{NaCl})$. Plasma was separated by centrifugation at $4{ }^{\circ} \mathrm{C}$ and stored at $-20{ }^{\circ} \mathrm{C}$ until the time for PRL measurement.

Saline (0.15 M NaCl), Ang II (Sigma, USA), haloperidol $\left(\mathrm{D}_{1} / \mathrm{D}_{2}\right.$ receptor antagonist, $\mathrm{RBI}$, USA), sulpiride $\left(\mathrm{D}_{2}\right.$ receptor antagonist, $\left.\mathrm{RBI}\right)$ or $\mathrm{SCH} 23390$ $\left(\mathrm{D}_{1}\right.$ receptor antagonist, $\left.\mathrm{RBI}\right)$ solutions were injected in a volume of $1 \mu \mathrm{l}$ during one minute with a Hamilton syringe connected by a polyethylene tubing (PE-10) and injecting needle filled with the solution to be injected. The injections into the MPOA were carried out $10 \mathrm{~min}$ $(\mathrm{NaCl}$, haloperidol, sulpiride or $\mathrm{SCH})$ and $20 \mathrm{~min}(\mathrm{NaCl}$ or Ang II) after basal bleeding (-20 min). The doses used for microinjections of drugs were based on literary data: 100 pmol of Ang II (Dornelles and Franci 1998a,b), $5 \mu \mathrm{g}$ of haloperidol (Weiss and Ettenberg 1986), $10 \mu \mathrm{g}$ of sulpiride (Morutto and Phillips 1997) and $10 \mu \mathrm{g}$ of SCH 23390 (Moses et al. 1995). A blood sample was withdrawn immediately after the second microinjection 


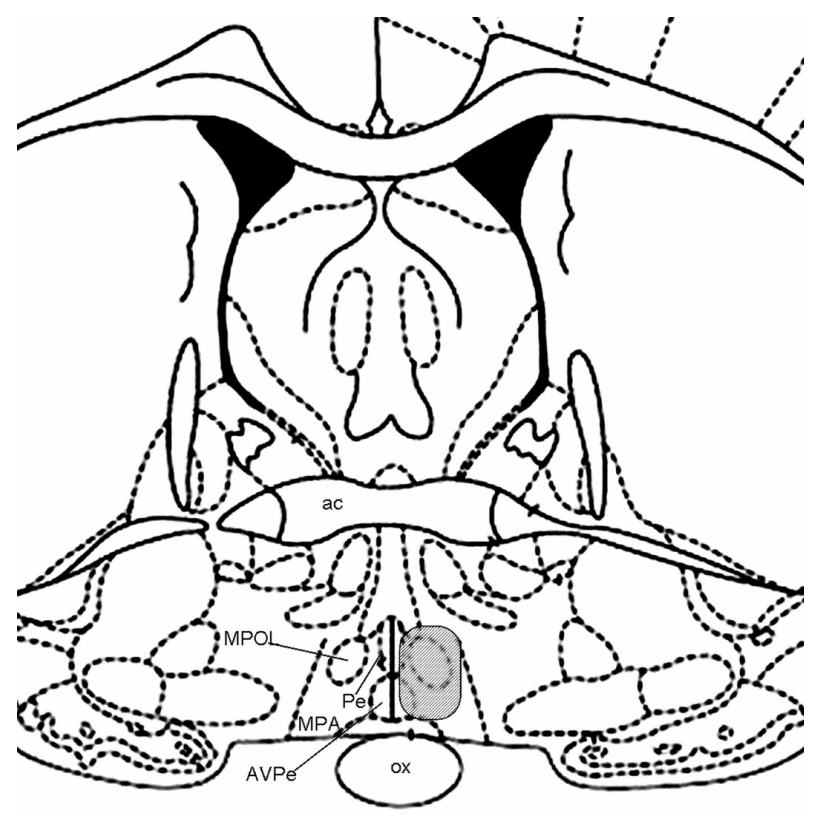

Fig. 1. The gray area represents the site of cannulas tips localization for microinjections in the preoptic area: ac - anterior commissure; ox - optic chiasm; MPA - medial preoptic area; MPOL -medial preoptic area, lateral part; $\mathrm{Pe}$ - periventricular nucleus; AVPe - anteroventral periventricular nucleus. (Adapted from Paxinos and Watson (1997); bregma $-0.26 \mathrm{~mm} /$ interaural $8.74 \mathrm{~mm})$.

(time zero). At the end of the experiment, the brains were removed and fixed in $10 \%$ formalin for histological analysis to confirm the localization of the cannula in the MPOA through frozen sections. Only animals with the confirmation of cannula placement in the MPOA (near $90 \%$ ) were included for hormonal measurement. The tips of the cannulas did reach the bearings of the MPOA in that region near median line as shown in schematic map (Fig. 1) adapted from Paxinos and Watson (1997).

\section{Radioimmunoassay (RIA)}

RIA for the measurement of plasma PRL was performed using a kit from the National Hormonal and Peptide Program of the National Institute of Diabetes and Digestive and Kidney Diseases (NIDDKD, USA). The lower detectable amount of $\mathrm{PRL} \mathrm{RP}_{3}$ standard was $0.2 \mathrm{ng} / \mathrm{ml}$, the interassay coefficient of variation was $11.7 \%$, and the intra-assay coefficient of variation was $5.5 \%$.

\section{Statistical analysis}

The data were analyzed statistically by analysis of variance for repeated measures, followed by Tukey's multiple range test using a computer software (SAS, USA). The level of significance was set at $\mathrm{P}<0.05$. Results are expressed as means \pm standard error.

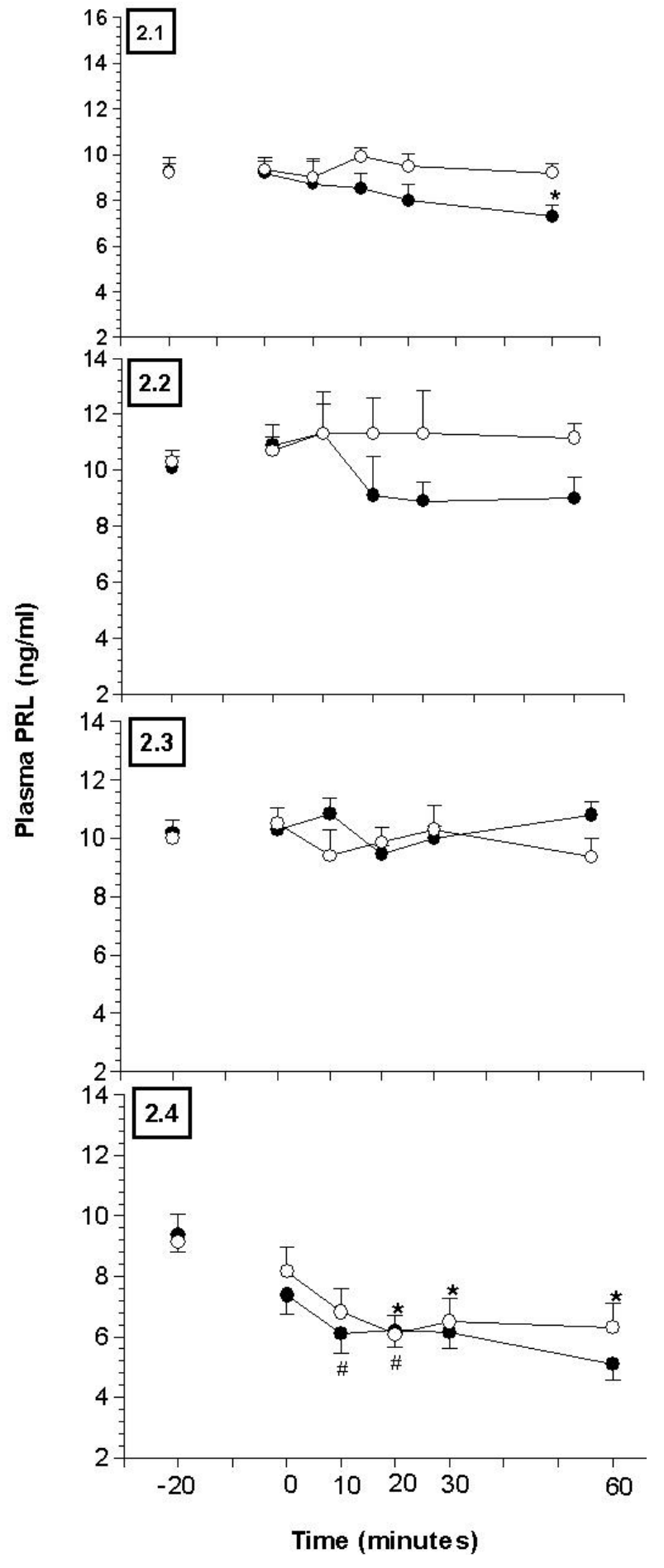

Fig. 2. Plasma $P R L$ after following microinjections in the medial preoptic area (MPOA) of ovariectomized rats: $\mathrm{NaCl}+\mathrm{NaCl}(\mathrm{O})$ and $\mathrm{NaCl}+$ Ang II $(\mathbf{O})$, panel 2.1; haloperidol $+\mathrm{NaCl}(\mathrm{O})$ and haloperidol + Ang II $(\mathbf{O})$, panel $2.2 ; \mathrm{SCH}+\mathrm{NaCl}(\mathrm{O})$ and $\mathrm{SCH}+$ Ang II (O),panel 2.3; sulpiride $+\mathrm{NaCl}(\mathrm{O})$ and sulpiride + Ang II (O), panel $2.4 ;{ }^{*} \mathrm{P}<0.05 \mathrm{vs} \mathrm{NaCl}+\mathrm{NaCl} ;{ }^{\#} \mathrm{P}<0.05 \mathrm{vs} \mathrm{NaCl}+$ Ang II. The number of animals in the groups was 10 to 14 .

\section{Results}

The basal plasma PRL at -20 min was around $10 \mathrm{ng} / \mathrm{ml}$ in the several unprimed ovariectomized groups 


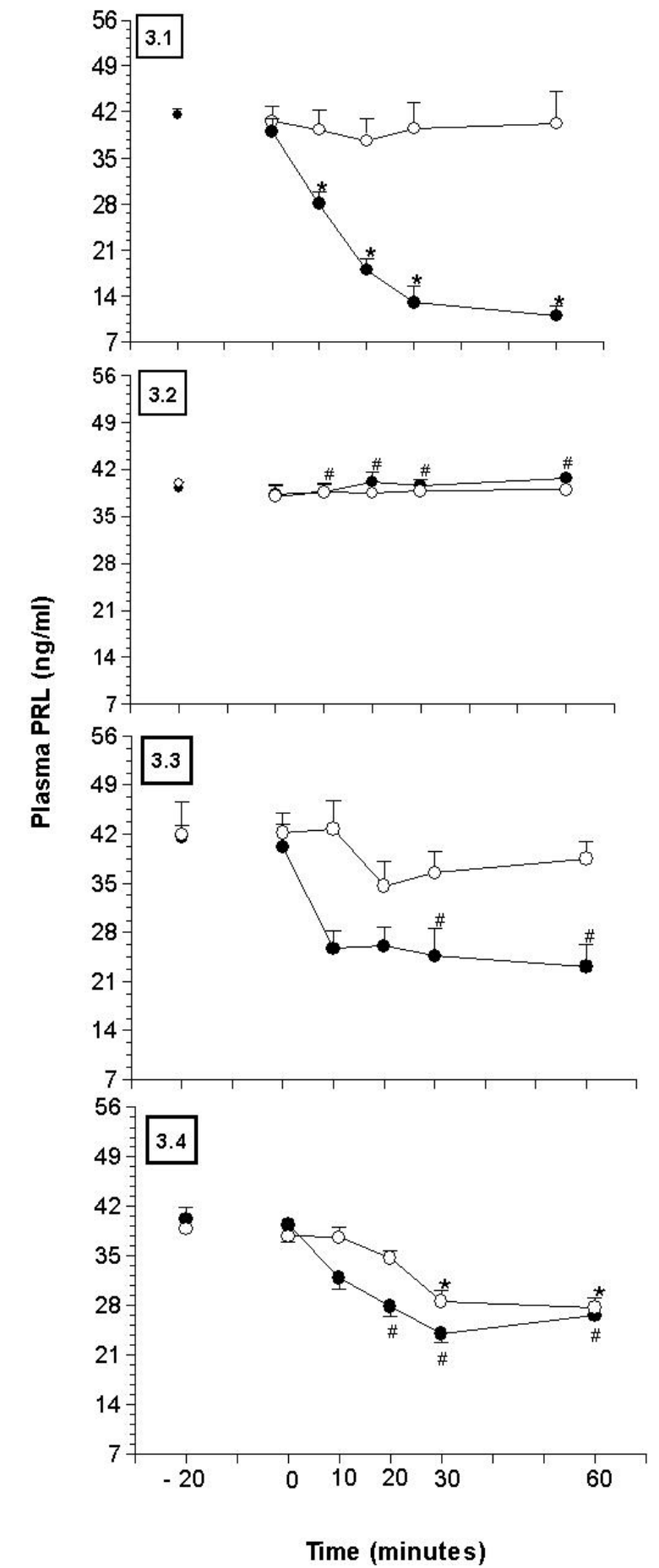

Fig. 3. Plasma PRL after following microinjections in the medial preoptic area (MPOA) of estrogen-primed ovariectomized rats: $\mathrm{NaCl}+\mathrm{NaCl}(\mathrm{O})$ and $\mathrm{NaCl}+$ Ang II (O), panel 3.1; haloperidol $+\mathrm{NaCl}(\mathrm{O})$ and haloperidol + Ang II $(0)$, panel 3.2; $\mathrm{SCH}+\mathrm{NaCl}$ (O) and $\mathrm{SCH}+$ Ang II (O), panel 3.3; sulpiride $+\mathrm{NaCl}(\mathrm{O})$ and sulpiride + Ang II (O), panel 3.4; ${ }^{*} \mathrm{P}<0.05$ vs $\mathrm{NaCl}+\mathrm{NaCl}$; ${ }^{\#} \mathrm{P}<0.05 \mathrm{vs} \mathrm{NaCl}+$ Ang II. The number of animals in the groups was 10 to 14 .

(Fig. 2) and $40 \mathrm{ng} / \mathrm{ml}$ in the several estrogen-primed ovariectomized groups (Fig. 3). The difference between unprimed ovariectomized groups and estrogen-primed ovariectomized groups was significant $(\mathrm{p}<0.001)$ and it indicates the known stimulatory action of estrogen on PRL secretion.

Microinjection of sulpiride $\left(\mathrm{D}_{2}\right.$ receptor antagonist) in the MPOA decreased plasma PRL in estrogen-primed $(\mathrm{F}=22.987$ for critical level of 2.353 , Fig. 3.4) and unprimed ( $F=5.216$ for critical level of 2.331, Fig. 2.4) ovariectomized rats while microinjections of saline (Fig. 2.1 and 3.1), haloperidol $\left(\mathrm{a}_{1} / \mathrm{D}_{2}\right.$ receptor antagonist, Fig. 2.2 and 3.2) or $\mathrm{SCH}\left(\mathrm{D}_{1}\right.$ receptor antagonist, Fig. 2.3 and 3.3) in the MPOA did not change plasma PRL. The decrease of plasma PRL was significant at 30 and $60 \mathrm{~min}$ in estrogen-primed (Fig. 3.4) and at 20, 30 and $60 \mathrm{~min}$ in unprimed ovariectomized rats (Fig. 2.4) that received sulpiride microinjection when compared with the control groups that received just microinjections of saline.

Figures 3.1 and 2.1 show that combined microinjections of Ang II with saline in the MPOA decreased the plasma PRL, respectively, in estrogenprimed ( $\mathrm{F}=213.67$ for critical level of 2.315) and unprimed ovariectomized $(\mathrm{F}=5.216$ for critical level of 2.331) rats. This diminishing was significant at 10, 20, 30 and $60 \mathrm{~min}$ in estrogen-primed (Fig. 3.1) and at $60 \mathrm{~min}$ in unprimed ovariectomized rats (Fig. 2.1) that received Ang II microinjection when compared with the respective control groups that received just microinjections of saline.

The combined microinjections of haloperidol (Fig. 2.2) or SCH (Fig. 2.3) with AngII in the MPOA did not change the plasma PRL in unprimed ovariectomized rats. However, plasma PRL decreased in the group that received the combined microinjections of sulpiride with Ang II ( $F=10.65$ for critical level of 2.331, Fig. 2.4). This decrease was significant at 10 and $20 \mathrm{~min}$ in the group subjected to sulpiride microinjection combined with Ang II when compared with the group subjected to the microinjection of $\mathrm{NaCl}$ combined with Ang II (Fig. 2.1)

The combined microinjections of haloperidol with Ang II (Fig. 3.2) in the MPOA in estrogen-primed ovariectomized rats did not change plasma PRL. However, there was a change of plasma PRL in the group that received combined microinjections of sulpiride with AngII ( $\mathrm{F}=97.744$ for critical level of 2.315, Fig. 3.4) or SCH with Ang II ( $\mathrm{F}=115.412$ for critical level of 2.315, Fig. 3.3). Plasma PRL at 20, 30 and $60 \mathrm{~min}$ in the group submitted to the microinjection of sulpiride combined with Ang II (Fig. 3.4), at 30 and $60 \mathrm{~min}$ in the group, which had received a microinjection of $\mathrm{SCH}$ combined 
with Ang II (Fig. 3.3) or at 10, 20, 30 and $60 \mathrm{~min}$ in the group received a microinjection of haloperidol combined with Ang II (Fig. 3.2) was significantly higher than in the group submitted to the microinjection of $\mathrm{NaCl}$ combined with Ang II (Fig. 3.1).

\section{Discussion}

Our results (Figs 2.1 and 3.1) are in agreement with a known stimulatory action of estrogen on PRL secretion which involves: a) a direct effect on the pituitary to induce synthesis, storage and release of PRL (Maurer and Gorski 1977, Vician et al. 1979), b) stimulation and inhibition of hypothalamic releasing and inhibiting factors of PRL secretion, respectively (Demarest et al. 1984, Pilotte et al. 1984), and c) altered sensitivity of the pituitary to the regulating factors of PRL secretion (Raymond et al. 1978).

We observed a significant decrease in plasma PRL after microinjection of sulpiride $\left(\mathrm{D}_{2}\right.$ receptor antagonist), but not of $\mathrm{SCH}$ ( $\mathrm{D}_{1}$ receptor antagonist) or haloperidol $\left(\mathrm{D}_{1} / \mathrm{D}_{2}\right.$ receptor antagonist) in the MPOA in estrogen-primed (Fig. 3) or unprimed (Fig. 2) ovariectomized rats.

The female hormonal state, the copulatory environment, and perineal stimulation modulate the activity of DA in the MPOA (Matuszewich et al. 2000). DA content (Crowley et al. 1978) and DA turnover (Wuttke et al. 1981) in the MPOA are lower in diestrus and proestrus than during estrus and metestrus. On the other hand, estrogen significantly reduces the DA turnover in the MPOA of ovariectomized rats (Hiemke et al. 1983). It has been suggested that the estrogen can block the DA neurotransmission in the MPOA at the postsynaptic level (Döcke et al. 1987).

How could the DA activity in the preoptic area influence the TIDA neurons that control the pituitary PRL secretion? PRL release involves two pathways, one originating from midbrain (ascending) and the other one from prefrontal cortex (descending), both projecting to the lateral and medial preoptic area. Then, the PRL release common pathway projects from the preoptic area caudally until the anterior hypothalamic area (Tindal and Knaggs 1972), which projects monosynaptically to the arcuate region (Kawakami and Sakuma 1976). Such a pathway would be well located to influence the system of DA neurons in the arcuate nucleus and hence to regulate the release of DA into the portal vessels. The stimulation of the rostral periventricular area might act by inhibiting transmission in dopaminergic neurons, which in turn, inhibit the release of DA from arcuate neurons and permit the release of PRL (Tindal and Knaggs 1972). Furthermore, the rostral periventricular region was found to be an effective site for stimulating prolactin release in the rat (Kawakami et al. 1973).

In situ hybridization studies indicate the presence of dopamine $D_{1}$ and $D_{2}$ receptors into the preoptic-anterior hypothalamic area (Tohyama and Takatsuji 1998).

Our results suggest a tonically active stimulation of PRL secretion by DA acting on $\mathrm{D}_{2}$ receptors in the MPOA via an estrogen-independent mechanism since the effect was observed in estrogen-primed and unprimed ovariectomized rats. However, we can not rule out a presynaptic $\mathrm{D}_{2}$ stimulatory autoreceptor regulation of endogenous DA release. In this case, the blockade of these receptors could induce an increase in DA endogenous that could act exclusively at postsynaptic $\mathrm{D}_{1}$ receptors to inhibit the PRL release. The effect of haloperidol could be explained by its ability to block the presynaptic $\mathrm{D}_{2}$ stimulatory autoreceptors as well the possynaptic effect through $D_{1}$ receptors. On the basis of recent observations obtained with pharmacological probes more selective for different DA receptor subtypes, it was concluded that a simultaneous activation or inhibition of $\mathrm{D}_{1}$ and $\mathrm{D}_{2}$ receptors blocks the actions on TIDA neurons mediated by these receptors (Durham et al. 1998). Thus, it is possible that simultaneous blockade of $\mathrm{D}_{1} / \mathrm{D}_{2}$ receptors by haloperidol in the MPOA has also suppressed any action of DA on PRL secretion, while the blockade of only $\mathrm{D}_{2}$ receptors by sulpiride did block the tonically stimulated PRL secretion.

Ang II significantly decreased plasma PRL (Fig. 3.1) in estrogen-primed ovariectomized rats (from close to $40 \mathrm{ng} / \mathrm{ml}$ at $-20 \mathrm{~min}$ to near $10 \mathrm{ng} / \mathrm{ml}$ at $60 \mathrm{~min}$ ). This lower level was similar to that found in unprimed ovariectomized rats at $-20 \mathrm{~min}$ (Fig. 2.1).

The endogenous angiotensin system in the preoptic-hypothalamic region does not seem to be involved in the maintenance of basal PRL secretion, since centrally administered Ang II receptor antagonists or angiotensin convertase inhibitors do not change PRL secretion in female or male rats (Dornelles and Franci 1998a, Myers and Steele 1989, 1991). However, the blockade of the central Ang II system by these compounds greatly facilitates stress- or estradiol-induced PRL secretion (Myers and Steele 1989, 1991, Saavedra 1992). Microinjection of Ang II into the MPOA 
decreased plasma PRL in estrogen-primed ovariectomized rats. This response was blocked by losartan, an $\mathrm{AT}_{1}$ receptor antagonist (Dornelles and Franci 1998a), but it was not altered by alpha- or betaadrenergic antagonists (Dornelles and Franci 1998b). Our data suggest that Ang II may antagonize the stimulatory action of estrogen on PRL secretion and thereby to prevent hypersecretion of this hormone. Other investigators have also proposed a possible function of the angiotensin system in the hypothalamus to limit the magnitude of PRL secretion (Saavedra 1992, Steele 1992).

There is colocalization of receptor mRNA, Ang II binding sites, Ang II immunoreactivity nerve terminals and Ang II receptors expression in the preoptichypothalamic area (Lenkei et al. 1997), morover Ang II binding sites (Gomes et al. 2006) and $\mathrm{AT}_{1}$ receptors (Moreno and Franci 2005) colocalized in the MPOA. There is consistent evidence about the regulation of brain Ang II receptors by estrogen and progesterone as well the interaction of this regulation with brain areas related with the control of gonadotropin and PRL secretion. Arcuate nucleus from cycling rats on the estrus day or estrogenprimed ovariectomized rats treated with progesterone presented an increased expression of $\mathrm{AT}_{1}$ receptors (Seltzer et al. 1993). $\mathrm{AT}_{1}$ receptors as well the expression of their mRNA are induced in the arcuate nucleus DA neurons of ovariectomized rats treated with estrogen and progesterone (Jöhren et al. 1997). Our group showed that Ang II receptors in the locus coeruleus, median preoptic nucleus and subfornical organ (Donadio et al. 2005) and ARC (Donadio et al. 2006) are upregulated in ovariectomized rats by treatment with estrogen and progesterone.

Is there any interaction between actions of Ang II and DA in the MPOA on PRL secretion? The microinjection of sulpiride or Ang II in the MPOA reduced PRL secretion in unprimed ovariectomized rats. However, the effect of sulpiride was observed earlier and persisted up to $60 \mathrm{~min}$ (Fig. 2.4), while the effect of Ang II was observed at $60 \mathrm{~min}$ (Fig. 2.1). Plasma PRL showed a similar profile in the group receiving the sulpiride/Ang II combination and the group receiving sulpiride/saline (Fig. 2.4). Thus, the effect of Ang II seems somehow to be masked by sulpiride. On the other hand, $\mathrm{SCH}$ (Fig. 2.3) and haloperidol (Fig. 2.2) blocked the effect of Ang II. Therefore, basal PRL secretion can be maintained in part by the stimulatory action of DA through $\mathrm{D}_{2}$ receptors in unprimed ovariectomized rats, while the Ang
II inhibitory action seems to depend on the action of DA mediated by $\mathrm{D}_{1}$ receptors, since $\mathrm{SCH}$ did block the effect of Ang II.

The inhibitory action of Ang II on PRL secretion in estrogen-primed ovariectomized rats was blocked by haloperidol, which acts through $\mathrm{D}_{1}$ and $\mathrm{D}_{2}$ receptors, and was partly reduced by sulpiride $\left(\mathrm{D}_{2}\right.$ receptor antagonist) and $\mathrm{SCH}\left(\mathrm{D}_{1}\right.$ receptor antagonist). Thus, the blockade of both receptors did impede the Ang II inhibitory effect, while the blockade of either receptor type $\left(D_{1}\right.$ or $\left.D_{2}\right)$ partly reduced the effect of Ang II. A previous study (Durham et al. 1998) showed that simultaneous activation or inhibition of $\mathrm{D}_{1}$ and $\mathrm{D}_{2}$ receptors blocked the actions on TIDA neurons mediated by these receptors.

Since PRL levels close to $40 \mathrm{ng} / \mathrm{ml}$ (at $-20 \mathrm{~min}$ ) decreased to near $25 \mathrm{ng} / \mathrm{ml}$ under the effect of sulpiride/ saline or of the sulpiride/Ang II combination in estrogen primed ovariectomized rats (Fig. 3.4), it seems that the effect of sulpiride masks the effect of Ang II also in this case, as was observed for unprimed ovariectomized rats.

Electrical stimulation of the MPOA decreased the magnitude of PRL surges in cycling rats during proestrous and estrous afternoon, in lactating rats during suckling as well in pregnant rats during day and night. These inhibitory mechanisms may be in the MPOA itself or another region whose projections continue through the MPOA (Wiersma and Kastelijn 1990). On the other hand, basal plasma levels of PRL decreased after microinjections of kainic acid in preoptic-anterior hypothalamic area (POA/AHA). The authors discovered that kainic acid caused extensive damage of medial region but not periventricular region of this area (Day et al. 1982). Studies of deafferentation of this area showed that POA neurons integrate some inhibitory tonic mechanism of basal PRL secretion (Jakubowski et al. 1988).

The dual participation of neurons in the preoptic area to control PRL secretion is a puzzle with only few known pieces. Furthermore, there are no specific studies about the relationship between dopamine receptors in this brain area and PRL secretion control, estrogen levels or angiotensin II action in rat. Thus, the present work represents some contribution to the limited literature on this subject.

Taken together, our results raise some conclusions regarding the integration of mechanisms for the control of PRL secretion: 1) the estrogen stimulatory action is mediated in part by the stimulatory action of DA through $\mathrm{D}_{2}$ receptors and thus, the sulpiride should reduce 
part of the estrogen effect on PRL secretion (Fig. 3), 2) the inhibitory action of Ang II depends on estrogen and it is mediated in part by the inhibitory action of DA through $\mathrm{D}_{1}$ receptors and in other part by inhibition of the stimulatory action of DA through $\mathrm{D}_{2}$ receptors and so, the haloperidol should inhibit the effect of Ang II by blockade of both receptors, 3) plasma PRL induced by estrogen is mediated by Ang II and DA actions in the MPOA so that very high levels of plasma PRL should be prevented by the inhibitory action of Ang II, while very low levels should be impeded by the stimulatory action of DA through $\mathrm{D}_{2}$ receptors.

\section{Conflict of Interest}

There is no conflict of interest.

\section{Acknowledgements}

We are grateful to Sonia Aparecida Zanon for technical assistance. Financial support: FAPESP and CNPq-Brazil.

\section{References}

ARAI Y, YAMANOUCHI K: Possible role of anterior input to the medial basal hypothalamus (MBH) in regulating prolactin release during pseudopregnancy in the ratinputs. Brain Res 83: 51-58, 1975.

BEN-JONATHAN N, HNASKO R: Dopamine as a prolactin (PRL) inhibitor. Endocr Rev 22: 724-763, 2001.

BJÖRKLUND A, LINDVALL O, NOBIN A: Evidence of an incerto-hypothalamic dopamine neurons system in the rat. Brain Res 89: 29-42, 1975.

BUNNEMANN B, FUXE K, GANTEN D: Extrarenal renin systems: the brain. In: The Renin-Angiotensin System. ROBERTSON JIS, NICHOLLS MG (eds), Mosby, London, 1993, 41.1-41.17.

CARRER HF, TALEISNICK S: Induction and maintenance of pseudopregnancy after interruption of preoptic hypothalamic connections. Endocrinology 86: 231-236, 1970.

CONRAD LCA, PFAFF DW: Axonal projections of medial preoptic area and anterior hypothalamic neurons. Science 190: 1112-1114, 1975.

CROWLEY WR, O' DONOHUE TL, JACOBOWITZ DM: Changes in CA content in discrete brain nuclei during the estrous cycle of the rat. Brain Res 147: 315-326, 1978.

DAY TA, BLESSING W, WILLOUGHBY JO: Noradrenergic and dopaminergic projections to the medial preoptic area of the rat. A combined horseradish peroxidase/catecholamine fluorescence study. Brain Res 193: 543-548, 1980.

DAY TA, OLIVER JR, MENADUE MF, DAVIES B, WILLOUGHBY JO: Stimulatory role for medial preoptic/ anterior hypothalamic area neurones in growth hormone and prolactin secretion. A kainic acid study. Brain Res 238: 55-63, 1982.

DEMAREST KT, RIEGLE GD, MOORE KE: Long-term treatment with estradiol induces reversible alterations in tuberoinfundibular dopaminergic neurons: a decreased responsiveness to prolactin. Neuroendocrinology 39: 193-200, 1984.

DÖCKE F, ROHDE W, OELSSNER W, SCHLEUSSNER E, GUTENSCHWAGER I, DÖRNER G: Influence of the medial preoptic dopaminergic activity on the efficiency of the negative estrogen feedback in the prepubertal and cyclic female rats. Neuroendocrinology 46: 445-452, 1987.

DONADIO MV, GOMES CM, SAGAE SC, FRANCI CR, ANSELMO-FRANCI JA, LUCION AB, SANVITTO GL: Angiotensin II receptors are upregulated by estradiol and progesterone in the locus coeruleus, median preoptic nucleus and subfornical organ of ovariectomized rats. Brain Res 1065: 47-52, 2005.

DONADIO MV, GOMES CM, SAGAE SC, FRANCI CR, ANSELMO-FRANCI JA, LUCION AB, SANVITTO GL: Estradiol and progesterone modulation of angiotensin II receptors in the arcuate nucleus of ovariectomized and lactating rats. Brain Res 1083: 103-109, 2006.

DORNELLES RCM, FRANCI CR: Action of $\mathrm{AT}_{1}$ subtype angiotensin II receptors of the medial preoptic area on gonadotropins and prolactin release. Neuropeptides 32: 51-55, 1998a.

DORNELLES RCM, FRANCI CR: Alpha- but not beta- adrenergic receptors mediate the effect of angiotensin II in the medial preoptic area on gonadotropins and prolactin secretion. Eur J Endocrinol 138: 583-586, 1998 b. 
DURHAM RA, JOHNSON JD, EATON MJ, MOORE KE, LOOKINGLAND KJ: Opposing roles for dopamine $\mathrm{D}_{1}$ and $\mathrm{D}_{2}$ receptors in the regulation of hypothalamic tuberoinfundibular dopamine neurons. Eur J Pharmacol 355 : 141-147, 1998.

FRANCI CR, ANSELMO-FRANCI JA, MCCANN SM: The role of endogenous atrial natriuretic peptide in resting and stress- induced release of corticotropin, prolactin, growth hormone and thyroid-stimulating hormone. Proc Natl Acad Sci, USA 89: 11391-11395, 1992.

FRANCI CR, ANSELMO-FRANCI JA, MCCANN SM: Angiotensinergic neurons physiologically inhibit prolactin, growth hormone, and thyroid-stimulating hormone, but not adrenocorticoptropic hormone, release in ovariectomized rats. Peptides 18: 971-976, 1997.

FREEMAN ME, KANYICSKA B, LERANT A, NAGY G: Prolactin: Structure, function, and regulation of secretion. Physiol Rev 80: 1523-1631, 2000.

GOMES CM, DONADIO MV, FRANSKOVIAK I, ANSELMO-FRANCI JA, FRANCI CR, LUCION AB, SANVITTO GL: Neonatal handling reduces angiotensin II receptor density in the medial preoptic area and paraventricular nucleus and locus coeruleus of female rats. Brain Res 1067: 177-180, 2006.

GRONAN RJ, YORK DH: Effects of angiotensin II and acetylcholine on neurons in the medial preoptic area. Brain Res 154: 172-177, 1978.

HIEMKE C, FROHNE D, BRUDER D, GHRAF R: Effect of oestradiol benzoate and progesterone on luteinizing hormone release and catecholamine turnover in the preoptic-hypothalamic brain area of ovariectomized rats. J Endocrinol 97: 437-445, 1983.

JAKUBOWSKI M, DOW RC, FINK G: Preoptic-hypothalamic pathways controlling nocturnal prolactin surges, pseudopregnancy, and estrous cyclicity in the rat. Neuroendocrinology 47: 13-19, 1988.

JÖHREN O, SANVITTO GL, EGIDY G, SAAVEDRA JM: Angiotensin II AT 1 A receptor mRNA expression is induced by estrogen-progesterone in dopaminergic neuron of the female rat arcuate nucleus. J Neurosci 17: 8283-8392, 1997.

KAWAKAMI M, SAKUMA Y: Electrophysiological evidences for possible participation of periventricular neurons in anterior pituitary regulation. Brain Res 101: 79-94, 1976.

KAWAKAMI M, KIMURA F, KONNO T: Possible role of the medial basal prechiasmatic area in the release of LH and prolactin in rats. Endocrinol Jap 20: 335-344, 1973.

KRULICH L, QUIJADA M, ILLNER P: Localization of prolactin inhibiting factor (PIF), prolactin releasing factor (PRF), growth hormone-RF (GRF) and GIF activities in the hypothalamus of the rat. Proc $53^{\text {rd }}$ Mtg Endocr Soc, 83, 1971.

LENKEI Z, PALKOVITS M, CORVOL P, LLORENS-CORTES C: Expression of angiotensin type-1 (AT 1$)$ and type-2 $\left(\mathrm{AT}_{2}\right)$ receptor mRNA in the adult rat brain: a functional neuroanatomical review. Front Neuroendocrinol 18: 383-439, 1997.

LIND RW, SWANSON LW, GANTEN D: Organization of angiotensin II immunoreactive cells and fibers in the rat central nervous system An immunohistochemical study. Neuroendocrinology 40: 2-24, 1985.

LINDVALL O, BJÖRHLUND A, SKAGERBERG G: Selective histochemical demonstration of dopamine terminal systems in rat di- and telencephalon: new evidence for dopaminergic innervation of hypothalamic neurosecretory nuclei. Brain Res 306: 19-30, 1984.

MATUSZEWICH L, LORRAIN DS, HULL EM: Dopamine release in the medial preoptic area of female rats in response to hormonal manipulation and sexual activity. Behav Neurosci 114: 772- 782, 2000.

MAURER RA, GORSKI J: Effects of estradiol-17beta and pimozine on prolactin synthesis in male and female rats. Endocrinology 101: 76-84, 1977.

MORENO AS, FRANCI CR: Angiotensin II receptors and estrogen receptors in neurons on preoptic area of female rats. Proc 35 ${ }^{\text {th }}$ Annual Mtg, Soc Neurosci, Washington, DC, Abstract: 521.12, 2005.

MORUTTO CL, PHILLIPS GD: Isolation rearing enhances the locomotor stimulant properties of intra-perifornical sulpiride, but impairs the acquisition of a conditioned place preference. Psychopharmacology 133: 224-232, 1997. 
MOSES J, LOUCKS JA, WATSON HL, MATUSZEVICH L, HULL EM: Dopaminergic drugs in the medial preoptic area and nucleus accumbens: effects on motor activity, sexual motivation, and sexual performance. Pharmacol Biochem Behav 51: 681-686, 1995.

MYERS LS, STEELE MK: The brain renin-angiotensin system and the regulation of prolactin secretion in female rats: Influence of ovarian hormones. J Neuroendocrinol 1: 299-303, 1989.

MYERS LS, STEELE MK: The brain renin-angiotensin system and prolactin secretion in the male rat. Endocrinology 129: 1744-1748, 1991.

PAN J-T, GALA RR: Central nervous system regions involved in the estrogen-induced afternoon prolactin surge. II. Implantation studies. Endocrinology 117: 388-395, 1985.

PAXINOS G, WATSON C: The Rat Brain in Stereotaxic Coordinates. Academic Press, San Diego,Compact $3^{\text {rd }}$ Edition, 1997.

PHILLIPS MI, SHEN L, RICHARDS EM, RAIZADA MK: Immunohistochemical mapping of angiotensin AT receptors in the brain. Regul Pept 44: 95-107, 1993.

PILOTTE NS, BURT DR, BARRACLOUGH CA: Ovarian steroids modulate the release of dopamine into hypophysial portal blood and the density of anterior pituitary $\left({ }^{3} \mathrm{H}\right)$ spiropene-binding sites in ovariectomized rats. Endocrinology 114: 2306-2311, 1984.

QUADRI F, BADOER E, STADLER T, UNGER T: Angiotensin II induced noradrenaline release from anterior hypothalamus in conscious rats: a brain microdialysis study. Brain Res 563: 137-141, 1991.

RAYMOND V, BEAULIEU M, LABRIE F, BOISSIER J: Potent antidopaminergic activity of estradiol at the pituitary level on prolactin release. Science 200: 1173-1175, 1978.

RETTORI V, MILENKOVIC L, RIEDEL M, MCCANN SM: The role of neuropeptide Y (NPY) in the control of gonadotropins and prolactin release in rat. Gynecol Endocrinol 4: 169-179, 1990.

SAAVEDRA JM: Brain and pituitary angiotensin. Endocr Rev 13: 329-380, 1992.

SAMSON WK, LUMPKIN MD, MCCANN SM: Evidence for a physiological role for oxytocin in the control of prolactin. Endocrinology 119: 554-561, 1986.

SAMSON WK, BIANCHI R, MOGG R: Evidence for a dopaminergic mechanism for the prolactin inhibitory effect of the atrial natriuretic peptide factor. Neuroendocrinology 47: 268-271, 1988.

SCHALLY AV, REDDING TW, ARIMURA A, DUPONT A, LINTHICUM GL: Isolation of gamma-amino butyric acid from pig hypothalami and demonstration of its prolactin release inhibiting (PIF) activity in vivo and in vitro. Endocrinology 100: 681-691, 1977.

SELTZER A, TSUTSUMI K, SHIGEMATSU K, SAAVEDRA JM: Reproductive hormones modulate angiotensin AT 1 receptors in the arcuate nucleus of the female rat. Endocrinology 133: 939-941, 1993.

SILVEIRA NA, FRANCI CR: Antisense mRNA for NPY-Y 1 receptors in the medial preoptic area increases prolactin secretion. Braz J Med Biol Res 32: 1161-1165, 1999.

STEELE MK: The role of brain angiotensin II luteinizing hormone and prolactin release. Trends Endocrinol Metabol 3: 295-301, 1992.

STEELE MK, NEGRO-VILAR A, MCCANN SM: Effect of angiotensin II on in vivo and in vitro release of anterior pituitary hormones in the female rat. Endocrinology 109: 893-899, 1981.

SUMNERS C, PHILLIPS MI: Central injection of angiotensin II alters catecholamine activity in rat brain. Am J Physiol 244: R257-R263, 1983.

TINDAL JS, KNAGGS GS: Pathways in the forebrain of the rat concerned with the release of prolactina. Brain Res 119: 211-221, 1977.

TOHYAMA M, TAKATSUJI K: Atlas of Neuroactive Substances and Their Receptors in the Rat, Oxford University Press, Oxford, 1998.

VICIAN L, SHUPNIK MA, GORSKI J: Effects of estrogen on primary ovine pituitary cell cultures: stimulation of prolactin secretion, synthesis and preprolactin messenger ribonucleic acid activity. Endocrinology 104: 736$743,1979$. 
WIERSMA J, KASTELIJN J: Electrophysiological evidence for a key control function of the medial preoptic area in the regulation of prolactin secretion in cycling, pregnant and lactating rats. Neuroendocrinology 51: 162-167, 1990.

WUTTKE W, MANSKY T, STOCK KW, SANDMANN R: Modulatory actions of estradiol on CA and GABA turnover and effects on serum PRL and LH. In: Steroid Regulation of the Brain. FUXE K, GUSTAFSSON JA, WETTERBERG L (eds), Pergamon Press, New York, 1981, pp 135-146.

WEISS F, ETTENBRG A: Comparison of cycling induced by unilateral intrastriatal microinjections of haloperidol, clozapine and CCK-8 in rats. Pharmacol Biochem Behav 24: 983-989, 1986. 